\title{
Genomic and neural analysis of the estradiol-synthetic pathway in the zebra finch
}

\author{
Sarah E London ${ }^{* 1,2}$ and David F Clayton 1,2,3
}

\begin{abstract}
Background: Steroids are small molecule hormones derived from cholesterol. Steroids affect many tissues, including the brain. In the zebra finch, estrogenic steroids are particularly interesting because they masculinize the neural circuit that controls singing and their synthesis in the brain is modulated by experience. Here, we analyzed the zebra finch genome assembly to assess the content, conservation, and organization of genes that code for components of the estrogen-synthetic pathway and steroid nuclear receptors. Based on these analyses, we also investigated neural expression of a cholesterol transport protein gene in the context of song neurobiology.
\end{abstract}

Results: We present sequence-based analysis of twenty steroid-related genes using the genome assembly and other resources. Generally, zebra finch genes showed high homology to genes in other species. The diversity of steroidogenic enzymes and receptors may be lower in songbirds than in mammals; we were unable to identify all known mammalian isoforms of the $3 \beta$-hydroxysteroid dehydrogenase and $17 \beta$-hydroxysteroid dehydrogenase families in the zebra finch genome assembly, and not all splice sites described in mammals were identified in the corresponding zebra finch genes. We did identify two factors, Nobox and NR1H2-RXR, that may be important for coordinated transcription of multiple steroid-related genes. We found very little qualitative overlap in predicted transcription factor binding sites in the genes for two cholesterol transport proteins, the 18 kDa cholesterol transport protein (TSPO) and steroidogenic acute regulatory protein (StAR). We therefore performed in situ hybridization for TSPO and found that its mRNA was not always detected in brain regions where StAR and steroidogenic enzymes were previously shown to be expressed. Also, transcription of TSPO, but not StAR, may be regulated by the experience of hearing song.

Conclusions: The genes required for estradiol synthesis and action are represented in the zebra finch genome assembly, though the complement of steroidogenic genes may be smaller in birds than in mammals. Coordinated transcription of multiple steroidogenic genes is possible, but results were inconsistent with the hypothesis that StAR and TSPO mRNAs are co-regulated. Integration of genomic and neuroanatomical analyses will continue to provide insights into the evolution and function of steroidogenesis in the songbird brain.

\section{Background}

Steroids are central to zebra finch (Taeniopygia guttata) neurobiology. They are essential for early developmental organization of the song control system, and they continue to modulate brain and behavior throughout life $[1,2]$. Although some steroids are supplied to the brain from the periphery, others including estradiol can be synthesized within the brain, either de novo from cholesterol or by metabolism of precursor steroids that originate in

* Correspondence: slondon@illinois.edu

${ }^{1}$ Institute for Genomic Biology, University of Illinois at Urbana-Champaign, Urbana, IL, USA

Full list of author information is available at the end of the article the periphery, as shown by evidence from biochemical enzyme activity assays, explant and dissociated culture analysis, molecular identification and neuroanatomical mapping of steroidogenic factors, and in vivo steroid measurements [1,3-19] London, Itoh, Lance, Ekanayake, Oyama, Arnold, Schlinger: Neural expression and posttranscriptional dosage compensation of the steroid metabolic enzyme $17 \beta-$ HSD type 4: submitted. Steroids synthesized within the brain, termed "neurosteroids," masculinize the song system and can be rapidly modulated by experience $[1,5,8]$. Steroids often act through nuclear receptor transcription factors, which can be abundant in the songbird brain, including in the song 
control system [20-23]. Thus the zebra finch brain has the capacity to both produce and respond to a variety of steroids that can alter neural function and song behavior.

Steroids are small molecule hormones derived from cholesterol through a series of enzymatic conversions (Figure 1). The first steroidogenic enzyme resides in the inner mitochondrial membrane, and the rate-limiting step of steroidogenesis is the transport of cholesterol across the outer mitochondrial membrane. Two major cholesterol transport proteins, which have been proposed to work in concert as part of a protein complex, are the steroidogenic acute regulatory protein (StAR) and the 18 $\mathrm{kDa}$ cholesterol transport protein (TSPO; previously named peripheral type benzodiazepine receptor) [24-29]. Steroid synthesis starts with the action of cytochrome P450 side chain cleavage (CYP11A1), which produces pregnenolone. Pregnenolone can be converted to either progesterone or dehydroepiandrosterone via the action of cytochrome P450 17 $\alpha$-hydroxylase/17,20 lyase (CYP17) or $3 \beta$-hydroxsteroid dehydrogenase $/ \Delta 5, \Delta 4$ isomerase (HSD3B1), respectively. Androstenedione is produced from progesterone through the activity of HSD3B1 and from dehydroepiandrosterone through the activity of CYP17. Androstenedione can be converted to testosterone or an estrogen, estrone, via the activity of $17 \beta$ hydroxysteroid dehydrogenases (HSD17B) or cytochrome P450 aromatase (CYP19), respectively. HSD17B can also convert estrone to estradiol, and CYP19 metabolizes testosterone into estradiol. Of note is the fact that multiple HSD3B and HSD17B types exist in other animals, and that several of HSD17B enzymes can use androgens and estrogens as substrates [30-32].

Steroids most commonly act by binding to nuclear receptors that dimerize, translocate to the nucleus, and function as DNA-binding transcription factors. The steroid receptors belong to nuclear receptor class 3 , and maintain the typical four-domain structure of receptors in the nuclear receptor superfamily [33]. There are four main nuclear receptors for the steroids produced along the estradiol-synthetic pathway: estrogens bind estrogen receptor alpha $(E R \alpha)$ and beta $(E R \beta)$; androgens bind androgen receptor (AR), and progesterone binds progestin receptors $(\mathrm{PR})$.

With the assembly of the zebra finch genome sequence, we are now in position for the first time to assess the organization and regulation of the network of genes that control steroid synthesis and function in the songbird brain. Starting with the set of Ensembl gene predictions for the zebra finch, we manually curated the assembled models for genes that encode the major components of the estradiol-synthetic pathway and related proteins, as well as four nuclear steroid receptors. We characterized the structure, diversity, and evolutionary conservation of these genes. This analysis led us to examine the neural expression patterns of a cholesterol transport protein in the context of song neurobiology.

\section{Results}

Characterization of steroidogenic genes in the zebra finch genome assembly

We used all available resources (including Ensembl gene models, alignments to brain expressed sequence tags (ESTs) and GenBank cDNA clone entries, and cross-species and functional domain homology searches) to identify the sequences of twenty steroid-related genes in the zebra finch genome assembly (Table 1). Of these, two genes code for cholesterol transport proteins (StAR and TSPO), five genes code for enzymes known to be active in

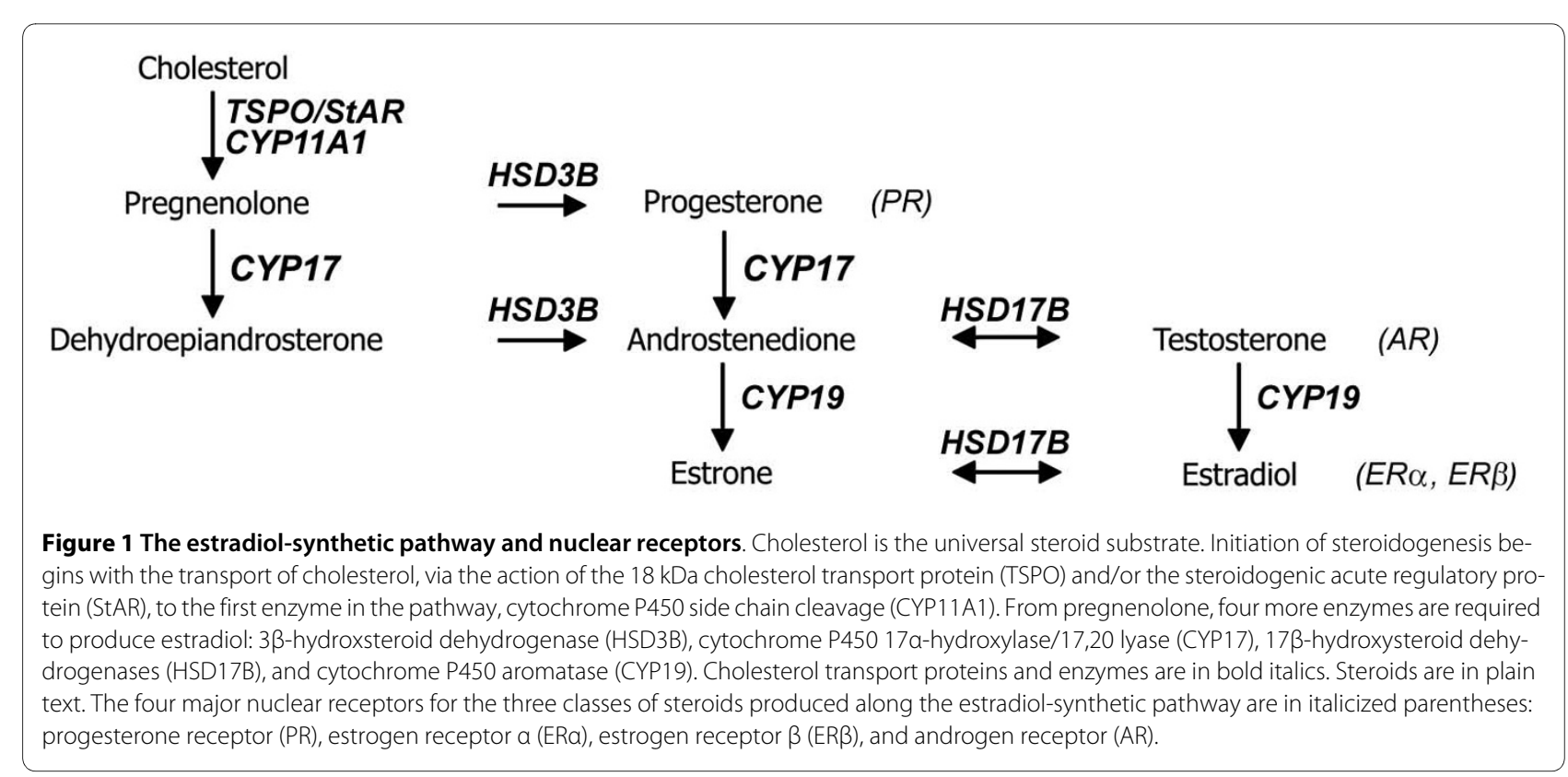


Table 1: Summary of steroid-related genes identified in the zebra finch genome assembly.

\begin{tabular}{|c|c|c|c|}
\hline & Ensembl model ID & Chromosomal location & Alternate location \\
\hline StAR & ENSTGUG00000004778 & chr22:2,790,291-2,803,402 & \\
\hline TSPO & ENSTGUG00000012033 & chr1A:64,600,558-64,604,825 & \\
\hline CYP11A1 & ENSTGUG00000016385 & chrUn:111,323,270-111,327,067 & \\
\hline HSD3B1 & ENSTGUG00000013351 & chr1:90,752,924-90,765,922 & \\
\hline HSD3B7 & ENSTGUG00000004368 & chr19:4700526-4724260 & \\
\hline CYP17 & ENSTGUG00000010219 & chr6:22,934,143-22,936,206 & \\
\hline HSD17B1 & ENSTGUG00000002682 & chr27:2,575,793-2,577,330 & \\
\hline HSD17B2 & ENSTGUG00000004388 & chr11:2,151,325-2,156,358 & chrUn:30,861,771-30,869,026 \\
\hline HSD17B3 & & chrZ:9,425,091-9,449,191 & \\
\hline HSD17B4 & ENSTGUG00000001154 & chrZ:24,424,040-24,517,666 & \\
\hline HSD17B6 & & chrUn: $44,543,014-44,547,896$ & \\
\hline HSD17B7 & ENSTGUG00000017081 & chr8_random:518,775-526,426 & \\
\hline HSD17B10 & ENSTGUG00000015458 & chrUn:14,031,915-14,032,480 & \\
\hline HSD17B11 & ENSTGUG00000002260 & chr4:8,273,553-8,281,927 & \\
\hline HSD17B12 & ENSTGUG00000010212 & chr5:19,883,132-19,948,030 & \\
\hline CYP19 & ENSTGUG00000006993 & chr10:9,056,446-9,074,753 & \\
\hline promoter 1a & & chr10:9,078,023-9,078,512 & \\
\hline promoter $\mathbf{1 b}$ & & chr10:9,052,768-9,083,661 & chrUn:18,857,683-18,860,112 \\
\hline ERa & ENSTGUG00000011249 & chr3:56,288,003-56,500,000 & \\
\hline ERß & ENSTGUG00000012942 & chr5:54,900,184-54,948,467 & \\
\hline PR & ENSTGUG00000012778 & chr1:77374938-77451302 & \\
\hline AR & ENSTGUG00000002760 & chr4A: 6,416,086-6,447,982 & \\
\hline
\end{tabular}

Genomic information for all twenty genes examined. Ensembl gene identifiers are listed for the eighteen genes with official models (HSD17B3 and HSD17B6 do not have Ensembl gene models). Chromosomal positions are also listed, as are the locations of either alternative mappings (HSD17B2) or annotated promoter regions (CYP19).

the estradiol-synthetic pathway in songbirds (CYP11A1, HSD3B1, CYP17, CYP19, HSD17B4), nine genes code for related HSD3B and HSD17B enzymes, some of which are likely to also be involved in the estrogen-synthetic pathway (HSD3B7, HSD17B1, HSD17B2, HSD17B3, HSD17B6, HSD17B7, HSD17B10, HSD17B11, HSD17B12), and four genes code for the primary nuclear receptors for the steroids produced in the estradiol-synthetic pathway (ER $\alpha, E R \beta, A R$, and PR).

Complete coding regions are present for the four receptor genes and for the HSD3B1, CYP19, HSD17B4, HSD17B6, HSD17B11 genes, but only partial gene sequences were identified for the other genes in the assembly. In cases where full length cDNA clone sequences were available, we could determine that incomplete gene models were due to assembly gaps. Some genome assembly gaps result in very small omissions (e.g. StAR is missing $~ 100$ bp of exon 1), but others are large (e.g. CYP11A1 and CYP17 are missing 5 and 4 exons, respectively). In the case of CYP17, we identified a genome contig in the trace archive (Contig 28.226) that codes for exon 8 and a portion of the 3'UTR that was not included in the current genome assembly (Figure 2). The structures of each of the zebra finch genes are illustrated by their evolutionarily conserved regions when compared to chicken or human genes in zpicture format (http:// zpicture.dcode.org/; Additional File 1, Figure S1).

HSD3B is a family with up to seven enzymes whose members each derive from unique genes, almost all of which are located along the same chromosome in human and mouse [31,34-38]. We used homology searches to try to identify zebra finch genes for all of the known HSD3B genes. HSD3B type 1 is annotated in the genome on chromosome 1. Several other types of HSD3B genes from other species show homology to this same location, but BLAT analysis with the zebra finch HSD3B1 cDNA clone sequence aligns only with this one position, suggesting that there is only one HSD3B gene in the zebra finch assembly. Homology searches with the conserved Rossmann catalytic domain did not identify any additional 


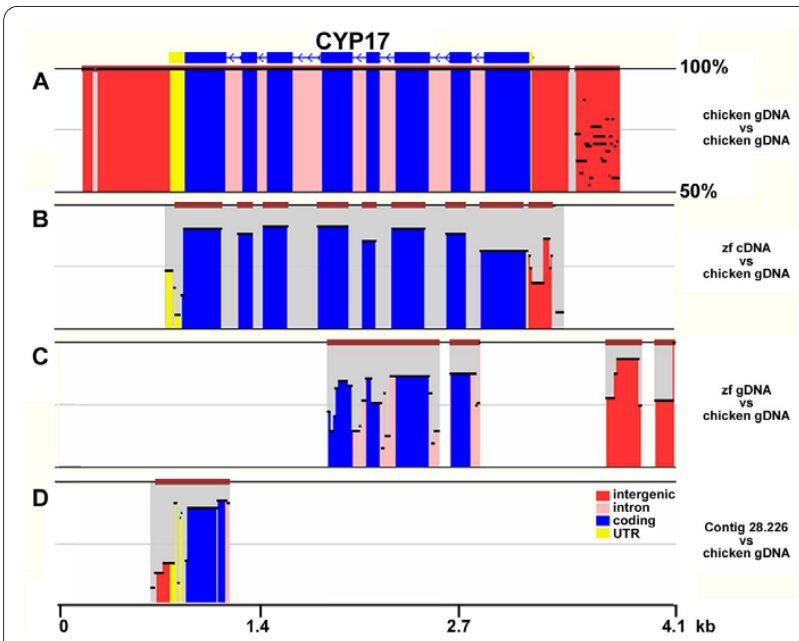

Figure 2 Alignments of chicken and zebra finch CYP17 sequences. Homology of chicken CYP17 gene (gDNA) and several zebra finch CYP17 sequences, as depicted in zpicture. A) Comparison of chicken gDNA to itself, to illustrate structure of the gene, B) comparison of a full length zebra finch CYP17 cDNA clone sequence (Accession numbers AY313844 and AY313845) to chicken gDNA, C) comparison of the CYP17 gene sequence obtained from the zebra finch genomic assembly to the chicken gDNA, showing substantial missing sequence, and D) comparison of zebra finch Contig 28.226 sequence, a contig that was not incorporated into the assembly, to the 3 ' end of the CYP17 gene. Note the scale of homology is from $50-100 \%$, and that arrows in top block denote the chicken gene sequence is oriented so that the $5^{\prime}$ end is on the right.

putative HSD3B genes on chromosome 1, further supporting the conclusion that the HSD3B1 gene is the only one on chromosome 1 . We did, however, identify an unannotated, incomplete gene for HSD3B type 7 on chromosome 19 by homology searches.

The HSD17B enzymes are also a family of similar enzymes. Fourteen HSD17B genes have been described to date in humans, and multiple HSD17B genes have also been cloned from or identified in the genomes of other mammals, fish, and chicken $[32,36,39]$. We attempted to find all fourteen genes in the zebra finch genome assembly. We identified genes for HSD17B 1-4, 6, 7, 10-12 in the assembly (numbering follows that of the human genes). We confirmed the available HSD17B1 genomic sequence (below). Two genes, HSD17B3 and HSD17B4, were mapped to the $\mathrm{Z}$ sex chromosome in the genome assembly; the HSD17B4 mapping is consistent with experimental data that show that this genes is localized to the $\mathrm{Z}$ chromosome [40] London, Itoh, Lance, Ekanayake, Oyama, Arnold, Schlinger: Neural expression and posttranscriptional dosage compensation of the steroid metabolic enzyme $17 \beta$-HSD type 4 : submitted. The $\mathrm{Z}$ chromosome position is of note because sex chromosome genes can be expressed at different levels in males and females and have been proposed to contribute to the sexual differentiation of the zebra finch song system [18,41-45]
London, Itoh, Lance, Ekanayake, Oyama, Arnold, Schlinger: Neural expression and post-transcriptional dosage compensation of the steroid metabolic enzyme $17 \beta$-HSD type 4: submitted. The HSD17B3 gene model is incomplete; there is one gap in the assembly that may remove several coding exons, but the assembly is uninterrupted for up to $65 \mathrm{~kb}$ outside of the boundaries of the gene model. It was therefore possible that more gene coding sequence could be obtained through manual curation of this stretch of the assembly. Our attempts to identify additional exons through homology searches were, however, unsuccessful. The HSD17B4 gene shares exon structure with mammalian and chicken HSD17B4 genes and contains only intronic assembly gaps; HSD17B4 was examined in more detail elsewhere [London, Itoh, Lance, Ekanayake, Oyama, Arnold, Schlinger: Neural expression and post-transcriptional dosage compensation of the steroid metabolic enzyme 17 $\beta$-HSD type 4: submitted].

Several steroidogenic genes have the potential to form alternatively spliced transcripts or utilize alternate promoters. StAR, TSPO, CYP11A1, ER $\alpha, E R \beta$, and AR are predicted to have alternative splice forms in other animals. We identified splice sites in the zebra finch StAR and TSPO genes that give rise to different length transcripts ([46]; Additional File 2, Figure S2). A model for CYP11A1 was not completed because of the large gap in genomic sequence, and we were unable to identify splice variants similar to those in mammals in the zebra finch $E R \alpha, E R \beta$, and AR genes. The first exon of the CYP19 gene is untranslated and contains promoter elements that regulate tissue-specific transcription e.g. [47-53]. In zebra finches as in mammals, there are several variants of exon 1; zebra finch brain CYP19 transcripts almost always use the "1a" exon [48]. Though not annotated as such, we identified the exon 1a sequence in the zebra finch genome assembly approximately $7 \mathrm{~kb}$ upstream of the first coding exon (Additional File 2, Figure S2).

\section{PCR confirmation of genomic sequence}

The Ensembl annotation of the genome assembly contains a predicted gene model for HSD17B1. As way of validating the genomic assembly sequence one of the genes that had not been previously cloned, we used the gene model to design PCR primers and successfully amplified the predicted HSD17B1 sequence from zebra finch genomic DNA (Additional File 3, Figure S3). However, we were still unable to obtain the sequence at the 3 ' end of the gene that is absent in the assembly due to a gap between contigs.

\section{Phylogeny and selection}

Cross-species multiple sequence alignments for each of the twenty genes demonstrated that functional domains were the most highly conserved regions of the genes and 
that the overall exon/intron structure of these genes is conserved across the fish, bird, and mammal species investigated (see Methods for species; nucleotide alignments not shown, genomic structural homology to chicken or human genes shown in Additional File 1, Figure S1). To examine the relationship between genes in the three families examined here, HSD3B, HSD17B, and the nuclear receptors, we constructed unrooted phylogenetic trees of each of these groups, using predicted protein sequences.

Phylogenetic analysis of mouse, human, zebrafish, chicken and zebra finch HSD3B proteins showed that the zebra finch HSD3B1 sequence is most similar to that of the chicken, and groups with the HSD3B1-6 protein sequences of the mouse and human (Figure 3). The HSD3B7 zebra finch and chicken sequences are more similar to HSD3B7 proteins in the other species, but showed less homology compared to human than even the zebrafish sequence.

To look at the phylogenetic relationship among HSD17B predicted proteins, we used all annotated HSD17B genes in human, mouse, zebrafish, and chicken, plus those we identified in zebra finch (Figure 4). In general, the zebra finch proteins segregated with the same enzyme type in chicken and the other species. This analysis modeled HSD17B4 and HSD17B7 proteins as independent branches, not closely related to any other HSD17B enzyme. Several other protein types, however,

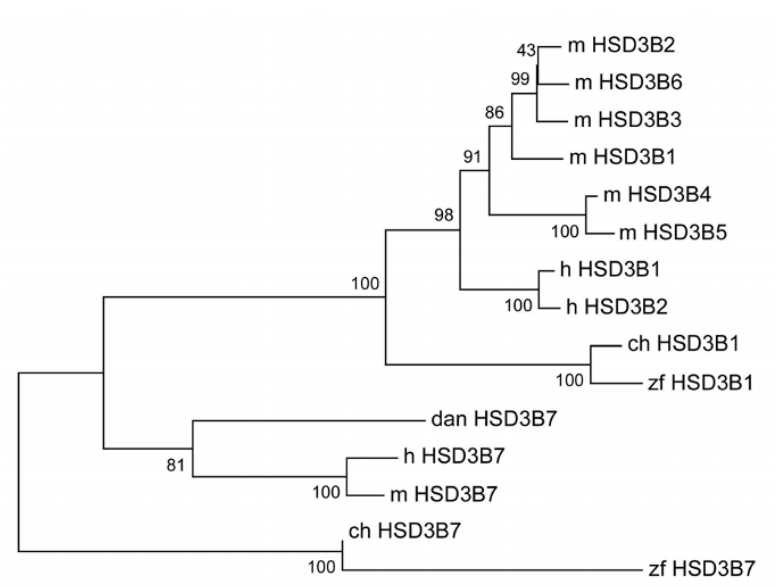

$$
0.2
$$

Figure 3 Unrooted phylogenetic tree of HSD3B predicted protein sequences. The two HSD3B genes identified in the zebra finch genome assembly, HSD3B1 and HSD3B7, show the closest similarity to the same HSD3B types in the chicken. The HSD3B1 protein sequence is predicted to be more similar to the HSD3B1-6 mammalian proteins than the HSD3B7 zebra finch protein is to the mammalian HSD3B7 protein. Bootstrap values are at branch points. Scale bar denotes substitution rate. $\mathrm{zf}=$ zebra finch, $\mathrm{ch}=$ chicken, $\mathrm{h}=$ human, $\mathrm{m}=$ mouse, dan $=$ zebrafish. showed more similarity to another. For example, the type 3 and 12 proteins were clustered together on the tree, as were types 2 and 6 .

We also examined the nuclear receptors (Additional File 4, Figure S4). The two types of ER segregated together, with the zebra finch ER $\alpha$ and $\operatorname{ER} \beta$ showing more similarity to their respective orthologs in other species than to each other. Similarly, the AR and PR predicted protein sequences were more similar to each other than to the ERs. For all four types of receptors, the zebra finch is most closely related to the chicken sequence. The zebrafish is the most distantly related to the mammalian proteins, and birds in some cases (ER $\beta$ and PR) show more similarity to the mammalian proteins than does the platypus.

\section{Distribution of predicted transcription factor binding sites}

Multiple steroidogenic enzymes need to be present in close proximity to locally synthesize a variety of steroids, including estradiol. The functional connection between these enzymes suggests the possibility that common transcriptional regulatory elements may be shared among the steroidogenic genes to direct their coordinated expression. To pursue this hypothesis, we used a set of Position Weight Matrix (PWM) predictions for specific transcription factor binding sites generated for the whole zebra finch genome as part of the primary analysis of the assembly [54]. We then tested whether any PWM sites were more abundant in territories surrounding steroid related genes than in the genome as a whole. When we used all 18 available Ensembl models, one PWM, NR1H2-RXR, was identified as significantly $(\mathrm{p}=0.045)$ overrepresented in the gene set with the SWAN algorithm [54,55]. No significantly overrepresented PWM sites were identified when subsets of the cholesterol transport and enzymes Ensembl models were used. However, when the four nuclear receptor genes were examined, Nobox was shown to be significantly $(\mathrm{p}=0.048)$ overrepresented according to the SLLR algorithm [55].

Two pairs of functionally related genes - StAR and TSPO, and CYP19 and HSD17B4 - had complete coding regions in the assembly, and few intronic gaps. We therefore inventoried and compared the PWM sites predicted to be in these genes to assess the potential for transcriptional co-regulation (Tables 2 and 3). Comparison of the PWM profiles in StAR and TSPO showed that no sites were common to both genes in the 5 '-focused region, and only $23 \%$ and $33 \%$ of them were shared when the whole gene was taken into account (7/30 for StAR, 7/21 for TSPO). Similarly, when PWM sites for CYP19 and HSD17B4 were compared, only one site was shared in the 5 '-focused region, while $89 \%$ and $61 \%$ (50/56 for CYP19, 50/81 for HSD17B4) were shared when the whole gene was considered. 


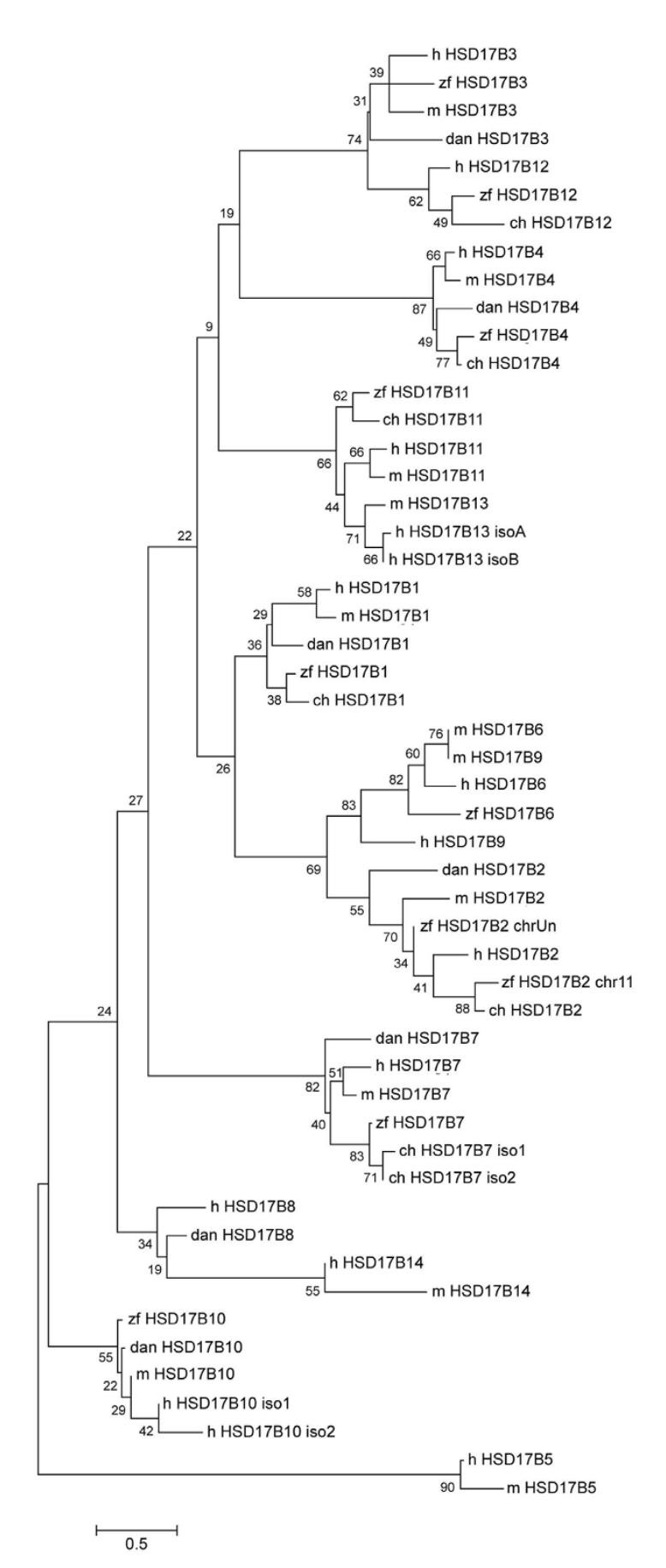

Figure 4 Unrooted phylogenetic tree of HSD17B predicted protein sequences. We identified nine HSD17B genes in the zebra finch assembly; these predicted proteins segregated with the same enzyme type in chicken and the other species. The unrooted tree models some enzymes (HSD17B4 and 7) as unique branches. Enzyme types predicted to be evolutionarily related (HSD17B3 and 12, and HSD17B2 and 6), are shown to be preserved in the zebra finch. Bootstrap support values are at branch points. Scale bar denotes substitution rate. $\mathrm{zf}=\mathrm{zebra}$ finch, $c h=$ chicken, $h=$ human, $m=$ mouse, dan = zebrafish, iso = isoform.

\section{Neural expression of TSPO}

The finding that StAR and TSPO shared few PWM sites suggested that these genes may have largely independent transcriptional regulatory mechanisms, which could result in distinct patterns of expression. Non-overlapping expression distributions would be inconsistent with recent models that propose that StAR and TSPO work together in a complex that is required for transporting cholesterol across the mitochondrial membranes for the initiation of steroidogenesis [26]. TSPO is one of the few components of the estradiol-synthetic pathway not yet examined in the zebra finch brain. We therefore utilized information from cDNA and microarray resources developed alongside the genome assembly to confirm that TSPO was expressed in the zebra finch brain, test whether or not it co-localized to brain areas that expressed StAR, and validate results from a zebra finch brain microarray that indicated that its mRNA was rapidly regulated after experience [56,57].

Several TSPO ESTs were identified in the zebra finch ESTIMA collection of brain cDNAs indicating that it was transcribed in the brain [57]. We used one of these clones to perform in situ hybridization to test if TSPO expression was neuroanatomically distributed within two functional regions known to express StAR and other steroidogenic genes: the nuclei of the song control system in adult males, and the cells along the proliferative zone of lateral ventricle in posthatch day 1 (P1) birds. In situ hybridization showed that TSPO is expressed in all four major song nuclei in adult male birds (Figure 5). The intensity of labeling within these nuclei is not noticeably above that in the surrounding brain, and its hybridization distribution is widespread. In P1 birds, TSPO hybridization occurred at low levels throughout the brain but was strikingly absent from the cell-dense region surrounding the lateral ventricle (Figure 5). Hybridization of adjacent sections with sense riboprobe did not show any labeling in adult or P1 brains, suggesting that the observed hybridization patterns are specific for TSPO.

We also measured TSPO and StAR expression in the auditory forebrain lobule (AL; [58]), a brain area required for song processing and learning [56,59-61]. Adult birds were either placed in silence or played 30 minutes of novel zebra finch song, and their brains were processed for in situ hybridization. In the $\mathrm{AL}$, there was a strong but non-significant trend of song condition on the intensity of TSPO labeling in cells $(\mathrm{p}=0.057)$ because labeling was less intense in the Novel song condition compared to the Silent condition (Figure 6). Hearing song had no effect on the total number of TSPO-labeled cells in AL ( $\mathrm{p}=0.202$ ). In one set of sections, we detected a main effect of sex on the number of TSPO-labeled cells ( $p=0.031$ ), with males having more cells than females in the AL, but this effect was not confirmed with a second, independent set of sec- 
Table 2: Qualitative listing of PWM predictions compiled from StAR and TSPO genes.

\begin{tabular}{|c|c|c|c|c|c|c|c|c|c|}
\hline & StAR & TSPO & StAR & TSPO & & StAR & TSPO & StAR & TSPO \\
\hline Ar & & & & & NFYA & & & & \\
\hline Arnt & & & & & NHLH1 & & & $\square$ & \\
\hline Arnt-Ahr & $\mathbf{\square}$ & & $\square$ & & Nkx2-5 & & & & \\
\hline Bapx1 & & $\mathbf{\square}$ & & $\square$ & NKX3-1 & & $\mathbf{\square}$ & & $\square$ \\
\hline CEBP & & $\mathbf{\square}$ & & $\square$ & Nobox & & & $\square$ & \\
\hline CREB 1 & & & $\square$ & & NR1H2-RXR & & & & \\
\hline Ddit3-Cebpa & & $\mathbf{\square}$ & $\square$ & $\square$ & NR2F1 & & & & \\
\hline E2F1 & & & & & NR3C1 & & $\mathbf{\square}$ & & $\square$ \\
\hline ELF5 & & & & & Pax 2 & & & & \\
\hline ELK1 & & & & & Pax4 & & & & \\
\hline En1 & & & & & Pax5 & & & $\square$ & \\
\hline ESR1 & & & $\square$ & $\square$ & Pax6 & & & $\square$ & \\
\hline ETS1 & $\mathbf{0}$ & & & $\square$ & $\mathrm{Pbx}$ & & & & \\
\hline Evi1 & & & & & Pdx1 & & & $\square$ & \\
\hline Fos & & & & $\square$ & PPARG & & & & $\square$ \\
\hline Foxa2 & & & & & PPARG-RXRA & & & & \\
\hline FOXC1 & & & & & Prrx2 & & & $\square$ & \\
\hline Foxd3 & & & & & REL & & & & \\
\hline FOXF2 & & $\mathbf{\square}$ & & $\square$ & RELA & & & $\square$ & $\square$ \\
\hline FOXI1 & & & & & REST & & & $\square$ & $\square$ \\
\hline FOXL1 & & & & & Roaz & $\mathbf{\square}$ & & $\square$ & \\
\hline Foxq1 & & & & & RORA_1 & & & & \\
\hline GABPA & & & $\square$ & & RORA_2 & & & & \\
\hline Gata1 & & & & & RORA1 & & & & \\
\hline GATA2 & & & & & RREB1 & $\mathbf{\square}$ & & $\square$ & \\
\hline GATA3 & & & & & RUNX1 & & $\mathbf{\square}$ & & $\square$ \\
\hline Gfi & & & & & RUSH1-alfa & & & & \\
\hline HAND1-TCF3 & & $\mathbf{\square}$ & & $\square$ & RXRA-VDR & & & & \\
\hline HLF & & & & & RXR-VDR & & & & \\
\hline HNF1A & & & & & Sox17 & & $\mathbf{\square}$ & $\square$ & \\
\hline HNF4 & & & & & Sox 5 & & & & $\square$ \\
\hline Hox11-CTF1 & & & & & SoX9 & & & & \\
\hline IRF1 & & $\mathbf{0}$ & $\square$ & $\square$ & SP1 & $\mathbf{\square}$ & & $\square$ & \\
\hline IRF2 & & & & & SPI1 & & & & \\
\hline KIf4 & $\mathbf{\square}$ & & $\square$ & & SPIB & & $\mathbf{\square}$ & & $\square$ \\
\hline Lhx3 & & $\mathbf{\square}$ & $\square$ & $\square$ & Spz1 & & & & \\
\hline MafB & $\mathbf{0}$ & & $\square$ & & SRF & & & & \\
\hline MAX & & & & & SRY & & & & \\
\hline MEF2A & & & & & Staf & & & & $\square$ \\
\hline MIZF & & & & & STAT1 & & & & \\
\hline Myb & & & & & $\mathbf{T}$ & & & & \\
\hline MYC-MAX & & & & & TAL1-TCF3 & & & & \\
\hline
\end{tabular}




\begin{tabular}{llll}
\hline Mycn & & TBP & \\
Myf & $\square$ & TCF1 & $\square$ \\
MZF1_1-4 & $\square$ & TEAD & $\square$ \\
MZF1_5-13 & $\square$ & TFAP2A & $\square$ \\
NFIL3 & $\square$ & TP53 & $\square$ \\
NF-kappaB & $\square$ & USF1 & $\square$ \\
NFKB1 & $\square$ & YY1 & $\square$ \\
NF-Y & & ZEB1 & $\square$ \\
& & ZNF42_1-4 & $\square$ \\
\hline
\end{tabular}

All 101 JASPAR PWMs that were mapped onto the zebra finch genome assembly are listed. Blocks in the row denote the presence of the PWM either in the 5 '-focused region (filled in blocks) or across the entire gene territory (open blocks) for StAR and TSPO.

tions from other birds analyzed the same way. Sex had no effect on the average intensity of cell labeling $(p=0.190)$, and there was no significant interaction between sex and song condition with respect to the number of TSPOlabeled cells $(\mathrm{p}=0.387)$ or the intensity of cell labeling ( $\mathrm{p}$ $=0.173$ ). We found no significant effects of song condition (cell number $\mathrm{p}=0.341$; labeling intensity $\mathrm{p}=0.538$ ), sex (cell number $\mathrm{p}=0.189$; labeling intensity $\mathrm{p}=0.099$ ), or the song condition by sex interaction (cell number $\mathrm{p}=$ 0.564 ; labeling intensity $\mathrm{p}=0.421$ ) on the level of StAR hybridization in AL.

\section{Discussion}

Steroids exert powerful effects on many physiological systems across animals. In the zebra finch, they are particularly relevant because they can be synthesized within the brain and may have a special role in the sexual differentiation of the developing song system and as rapid signaling molecules in the adult song system. We took advantage of the newly-released zebra finch genome assembly to investigate the structures of the steroid-related genes. We assess the diversity of their gene families and putative transcriptional regulatory elements, and contribute additional neuroanatomical expression data regarding the potential for regulated neurosteroidogenesis.

We first used homology searches to identify twenty steroid-related genes in the zebra finch genome assembly. After comparing zebra finch genome sequence to gene sequences from other species and zebra finch cDNA information, we determined that many of the genes were incomplete in the assembly, likely due to technical assembly gaps. As expected, cross-species analysis of the gene sequences did generally show high homology to genes in other species, and the preservation of major enzyme active sites and overall domain structure of the receptors.

Over half of the twenty genes we analyzed from the genome assembly belong to one of two enzyme families, HSD3B and HSD17B. We were, however, unable to identify the full complement of genes in either of these fami- lies as described in mammals. It is possible that zebra finches do have all of the HSD3B and HSD17B genes that mammals have and that their absence in the assembly simply reflects incomplete genome sequencing. But based on evolutionary theories of the expansion of these gene families and the phylogenetic analysis of their predicted protein sequences performed here, it is likely that there is a biological, not technical, basis for this difference in gene family sizes. For example, up to 7 different HSD3B genes have been discovered in other animals, each encoding a distinct enzyme. In mammals, genes for HSD3B1-6 encode steroid-metabolizing enzymes that are believed to have arisen from duplication events, in part because they are localized to the same chromosome [3537]. HSD3B7 is considered primarily a bile-synthesizing enzyme and may have evolved independently from the other HSD3B proteins, as it is localized to a different chromosome as shown here and in mammals [38]. Previously in the zebra finch, a cDNA for HSD3B1 had been cloned, and there was evidence for multiple HSD3B-like transcripts in both the gonads and the brain [3]. The zebra finch HSD3B1 gene was mapped to chromosome 1, but our homology searches were unable to identify any other HSD3B genes on this chromosome. Efforts to identify these genes in the chicken genome assembly were also unsuccessful. Our current findings therefore suggest that the HSD3B gene expansion that occurred in mammals did not occur in the avian lineage.

Similarly, we could identify only nine of the fourteen mammalian HSD17B genes in the zebra finch genome assembly. The enzymes of the HSD17B family catalyze reactions with different specificities and affinities for androgens and estrogens, as well as fatty acids, retinoids, and cholesterol [30,39,62]. Two HSD17B genes, HSD17B3 and HSD17B4, were mapped to the Z sex chromosome; other studies confirmed the $\mathrm{Z}$ chromosome localization of HSD17B4 [40] London, Itoh, Lance, Ekanayake, Oyama, Arnold, Schlinger: Neural expression and post-transcriptional dosage compensation of the ste- 
Table 3: Qualitative listing of PWM predictions compiled from CYP19 and HSD17B4 genes.

\begin{tabular}{|c|c|c|c|c|c|c|c|c|c|}
\hline & CYP19 & HSD17B4 & CYP19 & HSD17B4 & & CYP19 & HSD17B4 & CYP19 & HSD17B4 \\
\hline Ar & & & & & NFYA & & $\mathbf{\square}$ & $\square$ & $\square$ \\
\hline Arnt & & $\mathbf{\square}$ & & $\square$ & NHLH1 & & $\mathbf{\square}$ & & $\square$ \\
\hline Arnt-Ahr & & $\mathbf{\square}$ & $\square$ & $\square$ & Nkx2-5 & & & $\square$ & $\square$ \\
\hline Bapx1 & & & $\square$ & $\square$ & NKX3-1 & & & $\square$ & \\
\hline CEBP & & & $\square$ & $\square$ & Nobox & & & & $\square$ \\
\hline CREB 1 & & & $\square$ & $\square$ & NR1H2-RXR & $\mathbf{\square}$ & & $\square$ & $\square$ \\
\hline Ddit3-Cebpa & - & & $\square$ & $\square$ & NR2F1 & & & & $\square$ \\
\hline E2F1 & & $\mathbf{\square}$ & & $\square$ & NR3C1 & & & $\square$ & $\square$ \\
\hline ELF5 & & & & $\square$ & Pax 2 & & & & $\square$ \\
\hline ELK1 & & $\mathbf{\square}$ & & $\square$ & Pax4 & & & $\square$ & $\square$ \\
\hline En 1 & & & $\square$ & $\square$ & Pax5 & & $\mathbf{\square}$ & & $\square$ \\
\hline ESR1 & & & $\square$ & $\square$ & Pax6 & & & $\square$ & $\square$ \\
\hline ETS1 & & $\mathbf{\square}$ & $\square$ & $\square$ & $\mathrm{Pbx}$ & & & $\square$ & $\square$ \\
\hline Evi1 & & & $\square$ & $\square$ & Pdx1 & & & $\square$ & $\square$ \\
\hline Fos & & & & $\square$ & PPARG & & & $\square$ & $\square$ \\
\hline Foxa2 & & & & $\square$ & $\begin{array}{l}\text { PPARG- } \\
\text { RXRA }\end{array}$ & $\mathbf{\square}$ & & $\square$ & $\square$ \\
\hline FOXC1 & & & & $\square$ & Prrx2 & & & $\square$ & $\square$ \\
\hline Foxd3 & & & & & REL & & & $\square$ & $\square$ \\
\hline FOXF2 & - & & $\square$ & $\square$ & RELA & & & $\square$ & \\
\hline FOXI1 & & & $\square$ & $\square$ & REST & $\mathbf{\square}$ & & $\square$ & \\
\hline FOXL1 & & & $\square$ & $\square$ & Roaz & & $\mathbf{\square}$ & $\square$ & $\square$ \\
\hline Foxq1 & & & $\square$ & $\square$ & RORA_1 & & $\mathbf{\square}$ & $\square$ & $\square$ \\
\hline GABPA & & $\mathbf{\square}$ & $\square$ & $\square$ & RORA_2 & & $\mathbf{\square}$ & & $\square$ \\
\hline Gata1 & & & $\square$ & $\square$ & RORA1 & & $\mathbf{\square}$ & & \\
\hline GATA2 & & & $\square$ & $\square$ & RREB1 & & & & $\square$ \\
\hline GATA3 & & & $\square$ & $\square$ & RUNX1 & $\mathbf{\square}$ & & $\square$ & $\square$ \\
\hline Gfi & & & $\square$ & $\square$ & RUSH1-alfa & & & & $\square$ \\
\hline HAND1-TCF3 & & & $\square$ & $\square$ & RXRA-VDR & $\boldsymbol{\square}$ & & $\square$ & $\square$ \\
\hline HLF & & & & $\square$ & RXR-VDR & $\mathbf{\square}$ & & $\square$ & $\square$ \\
\hline HNF1A & & & & $\square$ & Sox17 & & & & $\square$ \\
\hline HNF4 & & $\mathbf{0}$ & & & Sox 5 & & & $\square$ & \\
\hline Hox11-CTF1 & & & & $\square$ & SOX9 & & & $\square$ & $\square$ \\
\hline IRF1 & $\mathbf{0}$ & & $\square$ & $\square$ & SP1 & & $\mathbf{\square}$ & & $\square$ \\
\hline IRF2 & & & & $\square$ & SPI1 & & & & $\square$ \\
\hline KIf4 & & & & $\square$ & SPIB & & $\mathbf{\square}$ & & $\square$ \\
\hline Lhx3 & $\mathbf{\square}$ & & $\square$ & $\square$ & Spz1 & $\mathbf{\square}$ & & $\square$ & $\square$ \\
\hline MafB & & $\mathbf{\square}$ & & $\square$ & SRF & $\mathbf{\square}$ & & $\square$ & $\square$ \\
\hline MAX & & & & & SRY & & & $\square$ & $\square$ \\
\hline MEF2A & & & $\square$ & & Staf & & & & \\
\hline MIZF & & $\mathbf{\square}$ & & & STAT1 & & & $\square$ & $\square$ \\
\hline Myb & & $\mathbf{\square}$ & $\square$ & $\square$ & $\mathbf{T}$ & & & $\square$ & $\square$ \\
\hline MYC-MAX & & & & & TAL1-TCF3 & & & $\square$ & $\square$ \\
\hline
\end{tabular}


Table 3: Qualitative listing of PWM predictions compiled from CYP19 and HSD17B4 genes. (Continued)

\begin{tabular}{|c|c|c|c|c|c|c|c|c|}
\hline Mycn & $\mathbf{\square}$ & & & TBP & & $\mathbf{\square}$ & $\square$ & $\square$ \\
\hline Myf & & & $\square$ & TCF1 & & & & $\square$ \\
\hline MZF1_1-4 & $\mathbf{\square}$ & & $\square$ & TEAD & & & & \\
\hline MZF1_5-13 & $\mathbf{\square}$ & & $\square$ & TFAP2A & & $\mathbf{a}$ & & $\square$ \\
\hline NFIL3 & & $\square$ & $\square$ & TP53 & & & & \\
\hline NF-kappaB & $\mathbf{\square}$ & & & USF1 & $\mathbf{\square}$ & $\mathbf{\square}$ & $\square$ & \\
\hline NFKB1 & & & & YY1 & $\mathbf{\square}$ & & $\square$ & $\square$ \\
\hline \multirow[t]{2}{*}{ NF-Y } & $\mathbf{\square}$ & $\square$ & $\square$ & ZEB 1 & & & & \\
\hline & & & & ZNF42_1-4 & & $\square$ & & $\square$ \\
\hline
\end{tabular}

All 101 JASPAR predictions mapped onto the zebra finch genome assembly are listed. Blocks in the row denote the presence of the PWM either in the 5 '-focused region (filled in blocks) or across the entire gene territory (open blocks) for CYP19 and HSD17B4.

roid metabolic enzyme $17 \beta$-HSD type 4 : submitted. This indicates the potential for different levels of expression or activity of these enzymes in males and females, as genes on the zebra finch $\mathrm{Z}$ chromosome undergo incomplete dosage compensation $[18,41]$. This leads to a male-bias in expression of Z-linked genes that may be relevant to the organization or function of the steroid-sensitive sexually dimorphic song system [18,41-45] London, Itoh, Lance, Ekanayake, Oyama, Arnold, Schlinger: Neural expression and post-transcriptional dosage compensation of the steroid metabolic enzyme 17ß-HSD type 4: submitted. Interestingly, the zebra finch HSD17B3 gene may be distinct from HSD17B3 in other species because we were unable to build a complete gene model based on crossspecies sequence homology. The HSD17B4 gene and protein was further investigated elsewhere to examine the potential for sex differences in neural expression and activity [45] London, Itoh, Lance, Ekanayake, Oyama, Arnold, Schlinger: Neural expression and post-transcriptional dosage compensation of the steroid metabolic enzyme $17 \beta$-HSD type 4 : submitted. Our inability to identify the five other HSD17B genes described in mammals may simply reflect low sequence homology across species $[30,39,62]$. Alternatively, it may be that some of the HSD17B types have evolved in mammals but not birds. Most HSD17B genes are thought to have evolved independently $[30,39,62,63]$; some of the missing enzymes display some functional redundancies with HSD17B enzymes we could identify in the zebra finch. Perhaps then the complement of HSD17B enzymes in zebra finches can perform all of the necessary reactions represented in the fourteen mammalian enzymes [32,39,63-66].

Phylogenetic analysis of the HSD3B and HSD17B predicted protein sequences suggested that the HSD17B zebra finch and mammalian isoforms are similar to each other, but that the bird HSD3B7 enzyme may have a slightly different function than that in mammals. For example, in the HSD17B family, HSD17B types 4 and 7 were placed on their own branches of the phylogenetic tree. This is consistent with the fact that the HSD17B4 enzyme has a unique set of catalytic structures and that HSD17B7 may have sequence structure that is optimized for cholesterol synthesis rather than the steroid or fatty acid metabolism more commonly performed by the other HSD17B enzymes [32,67-70]. Further, HSD17B types 3 and 12 were closely associated on the tree, as were types 2 and 6. HSD17B3 and HSD17B12 show higher sequence similarity in humans, too, and it has been previously postulated that HSD17B2 and HSD17B6 are derived from a common ancestral invertebrate enzyme [71-74]. On the other hand, phylogenetic modeling of the HSD3B predicted amino acid sequences suggested that the chicken and zebra finch HSD3B type 7 proteins are distinct from those in other species. If all of the steroidogenic conversions performed by the isozymes in mammals are necessary in birds, too, it may be that one of the two avian HSD3B enzymes can catalyze several reactions that are divided amongst HSD3B types 2-6 in other animals.

The extent to which different components in the steroidogenic pathway are co-expressed can influence the local steroid concentration and mixture, and the pattern of receptor expression can directly affect the signaling efficacy of those steroids. We therefore examined, both quantitatively and qualitatively, the profile of PWMs in these genes. Using Ensembl models and the genome-wide mapping of PWM sites, we identified two transcription factors, NR1H2-RXR and Nobox, that were overrepresented either in the entire set of genes or within the nuclear receptor genes, respectively. Both NR1H2-RXR and Nobox have known relationships with steroids and may therefore be relevant to steroid synthesis and signaling in the zebra finch $[75,76]$. A comparison of predicted PWM sites in CYP19 and HSD17B4, genes that code for estradiol synthesizing and metabolizing enzymes, suggested that many regulatory elements are common between the two genes and indeed, some transcription factors have been identified that regulate expression of 


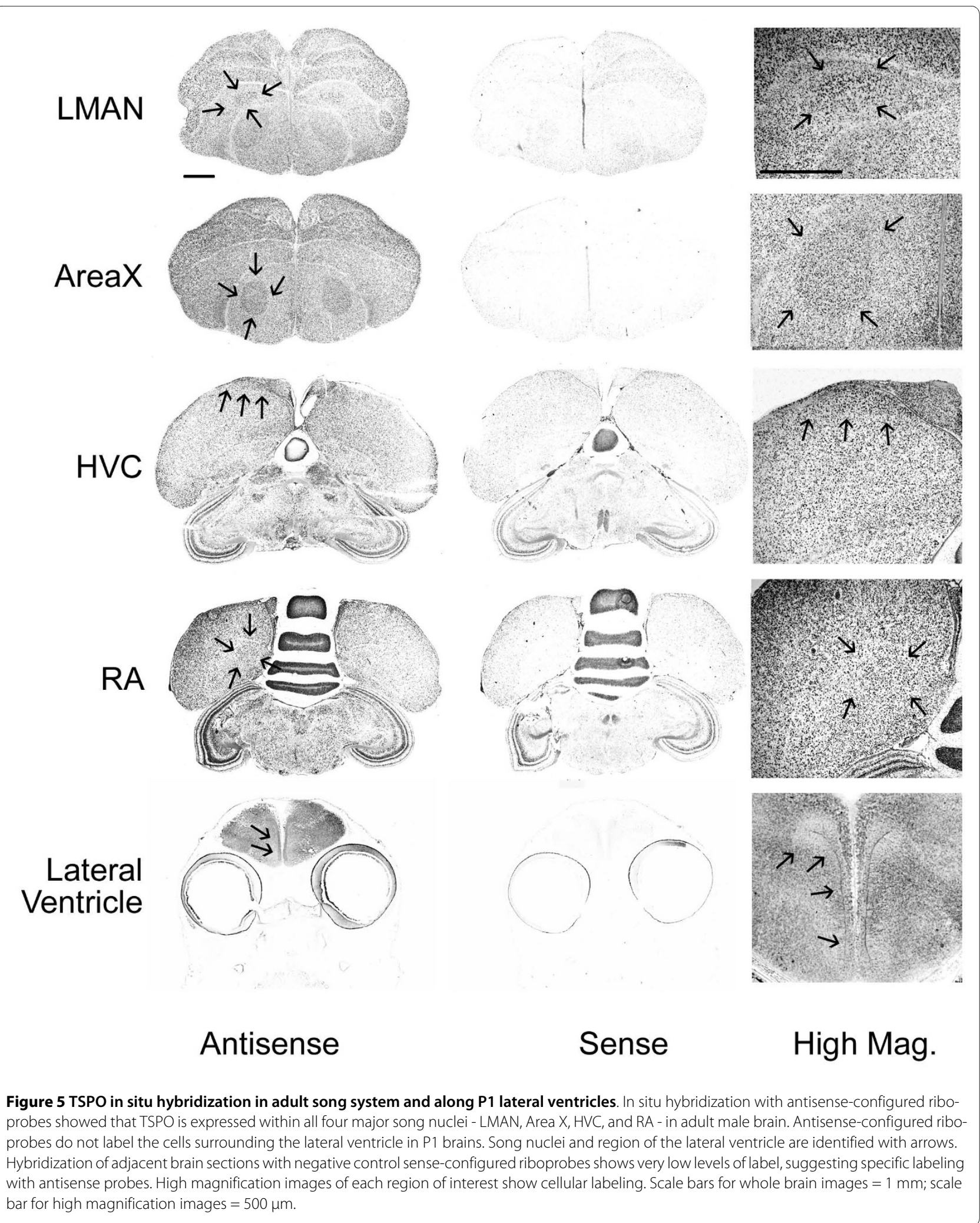

both genes in other systems such as steroidogenic cell lines [24,77-79]. Although accurately predicting active transcription factor binding sites is complicated and certainly not definitive, this analysis suggests some transcription factors to target in future experiments that investigate mechanisms of steroid regulation in the zebra finch.

The zebra finch brain produces estradiol; there is ample evidence from a variety of methods that demonstrate that steroidogenic enzymes are present and active within the 


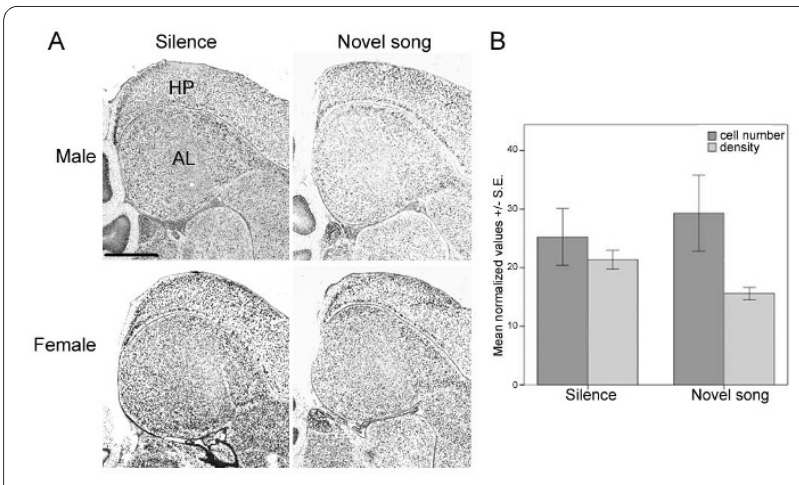

Figure 6 TSPO in situ hybridization in the adult AL after song playback experience. A) Representative images of AL (teardropshaped brain area in center of images) from males and females that heard either Silence or Novel song. B) The intensity of TSPO labeling showed a non-significant trend $(p=0.057)$ towards a decrease in birds that heard novel song. $\mathrm{AL}=$ auditory forebrain lobule, $\mathrm{HP}=$ hippocampus. Scale bar $=500 \mu \mathrm{m}$.

brain, and that brain slices, which cannot receive steroid precursors from the periphery, synthesize estradiol de novo [1,3-15,18,19,45] London, Itoh, Lance, Ekanayake, Oyama, Arnold, Schlinger: Neural expression and posttranscriptional dosage compensation of the steroid metabolic enzyme 17ß-HSD type 4: submitted. However, the precise pathways and locations of steroid synthesis in the brain are still uncertain. According to one recent proposal based on in vitro experiments, the StAR and TSPO proteins may work together in a complex that controls the transport of cholesterol from the outer mitochondrial membrane to the inner mitochondrial membrane, effectively controlling the initiation of steroidogenesis [26]. However, we observed minimal overlap in PWM sites associated with these two genes, and only partial neuroanatomical colocalization of the two mRNAs when our TSPO results here were compared with previous studies of StAR brain expression [3,19]. Notably, only one of the two transcripts is found in two brain regions relevant to the development and function of the steroid-sensitive song system: Area $\mathrm{X}$ of the adult male song circuit and the region surrounding the lateral ventricle in P1 birds. These results suggest either that StAR and TSPO coexpression are not absolutely necessary for steroidogenesis in brain tissue, or that neurosteroid synthesis is occurring at sites other than the current foci of research. As further evidence that transcription of these two genes is controlled differently, TSPO showed a strong trend towards regulated transcription in the AL after birds experienced song playbacks, consistent with a previous report, but levels of StAR mRNA were unchanged across the same conditions [56]. The current findings emphasize the importance of investigating these genes in the tissue where they function, and indicate that more experiments that delve into the cholesterol transport mechanisms for steroidogenesis in the brain are required.

\section{Conclusions}

We took advantage of the zebra finch genome assembly to integrate genomic and neural investigation of the enzymes and receptors of the estradiol-synthetic pathway. While mechanisms of steroid synthesis and action are largely conserved across phylogeny, the zebra finch and other birds may have evolved several unique features. Notably, genomic and molecular analysis of two major cholesterol transport proteins suggests that the regulation of steroidogenic initiation may be even more complex than previously. believed.

\section{Methods}

All procedures that involve animals were approved by the University of Illinois, Urbana-Champaign Institutional Animal Care and Use Committee.

\section{Identification of steroidogenic genes}

Whenever possible (StAR, TSPO, CYP11A1, HSD3B1, CYP17, CYP19, HSD17B4, ER $\alpha, E R \beta, A R, P R)$, we used existing zebra finch cDNA sequence to do homology searches of the zebra finch genome trace archive http:// www.ncbi.nlm.nih.gov/genome/seq/BlastGen/Blast-

Gen.cgi?taxid=59729 and the genome assembly http:// genome.ucsc.edu. When no zebra finch sequence was available, we used homology searches of the assembly to identify genes with available chicken sequences (HSD3B7, HSD17B2), or human sequence if a chicken gene model was not available (HSD17B1, HSD17B3, HSD17B6, HSD17B7, HSD17B10, HSD17B11, HSD17B12). We also used sequence from specific conserved functional domains for homology searches to attempt to identify enzyme genes. All genomic sequences were corrected using cDNA and protein information from zebra finch, chicken, mouse, and human in Apollo Genome Annotation Curation Tool [80]. We used zpicture http://zpicture.dcode.org/ to visualize conservation of gene structures and completeness of genomic sequences.

\section{PCR with genomic DNA}

We used PCR with genomic DNA to validate one of the Ensembl gene models for a gene that had not been cloned previously. DNA was extracted from zebra finch tissue samples and purified with DNeasy kit using manufacture's instructions (Qiagen, Valencia, CA). PCR was performed with HotStarTaq (Qiagen) for 55 cycles, products were gel extracted (Gel Extraction, Qiagen), and ligated into PCRScript Amp plamsid (Stratagene, La Jolla, CA). Clones were sequenced on both strands and their identities were confirmed by BLAST homology searches. We 
then aligned the clone sequence to that of the genome assembly to test for sequence matches.

\section{Phylogenetic analysis}

Predicted amino acid sequences for zebra finch genes were aligned with a combination of human, mouse, chicken, platypus, and zebrafish in MAFFT [81,82], and edited when necessary in BioEdit http:// www.mbio.ncsu.edu/BioEdit/bioedit.html. Unrooted neighbor-joining phylogenic trees of three gene families, HSD3B, HSD17B, and the nuclear receptors were constructed with MEGA4 [83,84]. Bootstrap support was performed with 1000 replications; consensus trees are shown.

\section{Distribution of transcription factor binding motifs}

We performed a statistical test for overrepresented PWM sites within the territories of the Ensembl gene models using the JASPAR http://jaspar.cgb.ki.se/ set of nonredundant and curated PWMs [54]. This tested if any of the JASPAR PWM sites were more abundant in the steroid-related gene models compared to their distribution across the whole genome assembly. We investigated several sets of genes: all of the 18 genes from our whole set of 20 that had Ensembl models, just StAR and TSPO, just CYP19 and HSD17B4, all of the predicted components of the estradiol-synthetic pathway (StAR, TSPO, CYP11A1, CYP17, HSD3B1, HSD17B1, HSD17B2, HSD17B4, CYP19), and the four nuclear receptors (ER $\alpha, E R \beta, A R$, and PR).

We also utilized the JASPAR PWM predictions across the whole genome assembly to perform a purely qualitative description of two pairs of functionally related genes that had complete coding regions and few gaps in the assembly: StAR and TSPO, and CYP19 and HSD17B4 [54]. We performed this inventory on two regions of the gene. One, focused on the putative 5 ' proximal regulatory region, captured the PWMs that were $5 \mathrm{~kb}$ upstream and $2 \mathrm{~kb}$ downstream of the 5'-most exon; the second, designed to identify regulatory elements scattered across the entire gene region, captured the PWMs within the boundaries of the entire gene plus those contained within $5 \mathrm{~kb}$ both $5^{\prime}$ and $3^{\prime}$ to the predicted gene model. This whole gene analysis was done with two caveats. To be conservative about what we included in this analysis, we did not extend the PWM characterization across an assembly gap unless there was cDNA evidence that the gene indeed spanned the gap, nor did we include PWMs that were within $5 \mathrm{~kb}$ of the gene of interest if an adjacent gene was predicted to fall within that boundary. In those cases, we only describe PWM that are non-overlapping with the adjacent gene.

\section{In situ hybridization}

The region along the lateral ventricles at P1 and the song control nuclei of adult males were previously identified to be brain areas that express genes in the estradiol-synthetic pathway $[3,9,19,85]$. Here, we performed in situ hybridization for TSPO on P1 ( $\mathrm{n}=3$ males, $\mathrm{n}=3$ females) and adult male $(\mathrm{n}=3)$ brains to determine whether or not it was also expressed in these two regions. P1 birds were removed from their nests in a breeding aviary and adult males were removed from single-sex holding aviaries located in a room that housed both males and females. Within 3 minutes of removal from their housing environment, birds were sacrificed and brains were flash frozen and sectioned to $20 \mu \mathrm{m}$ in the coronal plane. Sex of the P1 birds was confirmed by visual inspection of the gonads. The TSPO DIG-labeled riboprobe was in vitro transcribed using a zebra finch brain EST from the Songbird Neurogenomic Initiative's ESTIMA collection (GenBank Accession number DV952129) as the template [57]. This EST is predicted to contain the entire open reading from of the TSPO transcript and is highly specific for TSPO (e score $=1 \mathrm{e}-180)$. Sense riboprobes were also synthesized as negative hybridization controls. For every slide hybridized with the antisense probe, an adjacent slide was hybridized with the sense riboprobe for control. Labeling patterns on brain sections hybridized with antisense or sense probes were compared to evaluate if specific hybridization occurred along the lateral ventricles and in major song nuclei.

In situ hybridization was performed for all slides as follows [86]. The tissue was postfixed for 15 minutes in $4 \%$ paraformaldehyde ( $\mathrm{pH} 7.4)$, then washed $4 \times 5$ minutes in $0.02 \mathrm{M}$ KPBS (pH 7.4). The slides were equilibrated in TEA and treated with $0.25 \%$ acetic anhydride in TEA for 10 minutes, then rinsed in $2 \times$ SSC. Finally, the sections were dehydrated through increasing concentrations of ethanol. Hybridization with $500 \mathrm{ng}$ of riboprobe (hybridization solution: $50 \%$ formamide, $2 \times \operatorname{SSPE}[\mathrm{pH} 7.4], 2 \mathrm{mg} /$ $\mathrm{ml}$ tRNA, $1 \mathrm{mg} / \mathrm{ml}$ bovine serum albumin, $300 \mathrm{ng} / \mathrm{ml}$ polyadenylic acid, $0.1 \mathrm{M}$ dithiothreitol) proceeded for 3 hours at $65^{\circ} \mathrm{C}$. After hybridization, slides were rinsed in $2 \times \mathrm{SCC}$ at room temperature, then washed in $50 \%$ formamide $/ 1 \times \mathrm{SSC}$ for 10 minutes at $65^{\circ} \mathrm{C}$ with $2 \times 20$ minute final high stringency washes in $0.1 \mathrm{X} \mathrm{SSC}$, all at $65^{\circ} \mathrm{C}$. Slides were then placed in blocking buffer (1\% blocking reagent (Roche Applied Science, Indianapolis, IN) in buffer A (100 mM Tris [pH 7.5], $150 \mathrm{mM} \mathrm{NaCl}$, and $0.05 \%$ Triton $\mathrm{X}-100)$ at $4^{\circ} \mathrm{C}$ overnight. The next day, slides were rinsed in buffer $\mathrm{A}$ and incubated for 3 hours at room temperature with alkaline phosphatase conjugated anti-DIG antibody (Roche Applied Science) diluted 1:5000 in blocking buffer. Slides were washed $4 \times 5$ minutes in buffer A, then in buffer B (100 mM Tris [pH 9.5], $100 \mathrm{mM}$ $\mathrm{NaCl}$, and $50 \mathrm{mM} \mathrm{MgCl}_{2}$ ) for $10 \mathrm{~min}$. Color detection was performed with BCIP/NBT alkaline phosphatate substrate (Sigma-Aldrich, St. Louis, MO).

A previous study reported that TSPO mRNA showed a relatively rapid (within 30 minutes) decrease in levels in 
the AL after an adult male bird heard novel conspecific song [56]. Therefore, we also used in situ hybridization to confirm this finding and extend the investigation of TSPO expression in the AL to females. We also performed in situ hybridization for StAR using a clone previously described to compare TSPO and StAR mRNA changes after song playback experience [3]. We used adult male and adult female birds $(\mathrm{n}=3$ each sex) and exposed them to a standard song playback paradigm. Birds, who had been group-housed in single sex aviares in a room that housed both males and females, were removed from this communal setting and placed individually in a sound isolation chamber overnight. The next morning, birds were either played a zebra finch song unfamiliar to the bird for 30 minutes (one song bout every 10 seconds, for a total of 180 bouts; "Novel song") or left in silence ("Silence"), and sacrificed immediately after song playback ceased (or, for the Silence birds, within 30 minutes of the Novel song birds). To ensure that the song used for playback was unfamiliar to the experimental birds, we used a song recorded more than 10 years ago from a bird that was no longer present in the aviary population. Brains were extracted, flash frozen, and sectioned in the sagittal plane to $12 \mu \mathrm{m}$. In situ hybridization was performed on three AL sections $\sim 340$ $\mu \mathrm{m}$ apart to represent the medial-lateral extent of the auditory forebrain for each bird. Sections were hybridized with the TSPO and StAR riboprobes under the conditions described above [86].

Low magnification images of the adult male coronal brain sections were captured with a Nikon slide scanner (Super Coolscan 8000ED; Nikon Inc., Melville, NY). Images of P1 brains, individual song nuclei, and AL-containing brain sections were digitally captured on an AxioImager A1 Microscope (Carl Zeiss Microimaging, Thornwood, NJ) with a CCD camera (Microfire; Optronics, Goleta, CA). Representative in situ hybridization images shown were modified for contrast to highlight levels and areas of gene expression; modifications were performed equally for all images of a set.

The number and intensity of labeled cells in the AL was quantified within the entire AL and the adjacent nonauditory hippocampus (HP) for control purposes using ImageProPlus 4.5.1 (MediaCybernetics; Bethesda, MD) [87]. To remove potential differences in AL staining pattern across slides or from non-specific background staining, each AL value was normalized to the HP value on the same section. We then calculated a "total AL" value by summing the normalized values for all the three AL sections obtained in each bird. Normalized AL values were analyzed with two-way ANOVA (SPSS, Chicago, IL; $\alpha=$ 0.05 ) to test for effects of sex, song condition, and the sex by song condition interaction.

\section{Additional material}

\begin{abstract}
Additional file 1 Figure S1 - Conservation of gene structure for nineteen zebra finch genes, represented by zpictures. Zebra finch

sequences from the genomic assembly, and when available, full length

cDNA clone sequences, aligned to annotated genes to show evolutionarily conserved regions. When annotated, chicken genes were used as the base gene, otherwise the human gene was used. Percent sequence homology of regions above $50 \%$ similarity is depicted by the height of the colored

bars. Direction of arrows at the top of each gene's alignment indicates the 5 ' to 3 'direction of the base sequence.
\end{abstract}

Additional file $\mathbf{2}$ Figure S2 - Gene models showing alternative transcripts. Images of gene models corrected in Apollo Genome Annotation Curation Tool, showing predicted alternative transcripts based on evidence in other species. Position on the chromosome is depicted by the scale across the bottom of each gene. Dark blue portion denotes coding sequence, light blue denotes untranslated regions, green and red stripes represent position of translational start and stop codons, respectively.

Additional file 3 Figure S3 - Alignment of the HSD17B1 sequence from the zebra finch assembly and from the clone obtained from PCR amplification from zebra finch genomic DNA. Sequence alignment of the genomic HSD17B1 gene from the assembly aligned in ClustalX to the clone amplified directly from zebra finch DNA, validating a portion of this sequence.

Additional file 4 Figure S4 -Unrooted phylogenetic tree of nuclear receptor predicted protein sequences. Unrooted phylogenetic trees of the four nuclear receptor types examined model the zebra finch ER receptor subtypes as more similar to each other than AR and PR, which are more closely related to each other. Cross-species positioning within each receptor type show evolutionary changes between birds and mammals. Bootstrap support values are at branch points. Scale bar denotes substitution rate. $\mathrm{zf}=$ zebra finch, $\mathrm{ch}=$ chicken, $\mathrm{h}=$ human, $\mathrm{m}=$ mouse, dan = zebrafish, platy $=$ platypus, iso $=$ isoform.

\section{Authors' contributions}

SEL designed, performed, and interpreted the experiments and analyses, and wrote the manuscript. DFC participated in the design of experiments and analyses and contributed to manuscript writing. Both authors read and approved this manuscript.

\section{Acknowledgements}

We thank Chris Balakrishnan and James Lee for help with the phylogenetic analysis, Lisa Stubbs and Saurabh Sinha for consultations on the transcription factor binding analysis and access to the PWM statistical comparison program, and Barney Schlinger for helpful comments on the manuscript. This study was supported by NIH RO1 NS045264 to DFC and NINDS Postdoctoral NRSA NS554132 to SEL.

\section{Author Details}

${ }^{1}$ Institute for Genomic Biology, University of Illinois at Urbana-Champaign, Urbana, IL, USA, 2Beckman Institute of Advanced Science and Technology, University of Illinois at Urbana-Champaign, Urbana, IL, USA and ${ }^{3}$ Department of Cell and Developmental Biology, University of Illinois at Urbana-Champaign, Urbana, IL, USA

Received: 16 December 2009 Accepted: 1 April 2010 Published: 1 April 2010

\section{References}

1. London SE, Remage-Healey L, Schlinger BA: Neurosteroid production in the songbird brain: A re-evaluation of core principles. Front Neuroendocrinol 2009, 30:302-314.

2. Wade J, Arnold AP: Sexual differentiation of the zebra finch song system. Ann N Y Acad Sci 2004, 1016:540-559.

3. London SE, Monks DA, Wade J, Schlinger BA: Widespread capacity for steroid synthesis in the avian brain and song system. Endocrinology 2006, 147:5975-5987.

4. Schlinger BA, Arnold AP: Brain is the major site of estrogen synthesis in a male songbird. Proc Natl Acad Sci USA 1991, 88:4191-4194.

5. Remage-Healey L, London SE, Schlinger BA: Birdsong and the neural production of steroids. J Chem Neuroanat 2009 in press. 
6. Cam V, Schlinger BA: Activities of aromatase and 3beta-hydroxysteroid dehydrogenase/delta4-delta5 isomerase in whole organ cultures of tissues from developing zebra finches. Horm Behav 1998, 33:31-39.

7. Freking F, Ramachandran B, Schlinger BA: Regulation of aromatase, 5 alpha- and 5 beta-reductase in primary cell cultures of developing zebra finch telencephalon. J Neurobiol 1998, 36:30-40.

8. Holloway CC, Clayton DF: Estrogen synthesis in the male brain triggers development of the avian song control pathway in vitro. Nat NeurosCi 2001, 4:170-175.

9. London SE, Boulter J, Schlinger BA: Cloning of the Zebra Finch Androgen Synthetic Enzyme CYP17: A Study of Its Neural Expression throughout Posthatch Development. J Comp Neurol 2003, 467:496-508.

10. Saldanha CJ, Tuerk MJ, Kim YH, Fernandes AO, Arnold AP, Schlinger BA: Distribution and regulation of telencephalic aromatase expression in the zebra finch revealed with a specific antibody. J Comp Neurol 2000 423:619-630.

11. Schlinger BA, Arnold AP: Circulating estrogens in a male songbird originate in the brain. Proc Natl Acad Sci USA 1992, 89:7650-7653.

12. Schlinger BA, Amur-Umarjee $S$, Shen P, Campagnoni AT, Arnold AP: Neuronal and non-neuronal aromatase in primary cultures of developing zebra finch telencephalon. J Neurosci 1994, 14:7541-7552.

13. Schlinger BA, Amur-Umarjee S, Campagnoni AT, Arnold AP: 5 betareductase and other androgen-metabolizing enzymes in primary cultures of developing zebra finch telencephalon. J Neuroendocrinol 1995, 7:187-192.

14. Schlinger BA, Lane $\mathrm{NI}$, Grisham W, Thompson L: Androgen synthesis in a songbird: a study of cyp17 (17alpha-hydroxylase/C17,20-lyase) activity in the zebra finch. Gen Comp Endocrinol 1999, 113:46-58

15. Shen P, Schlinger BA, Campagnoni AT, Arnold AP: An atlas of aromatase mRNA expression in the zebra finch brain. J Comp Neurol 1995, 360:172-184.

16. Tam H, Schlinger BA: Activities of 3beta-HSD and aromatase in slices of developing and adult zebra finch brain. Gen Comp Endocrinol 2007, 150:26-33.

17. Vanson A, Arnold AP, Schlinger BA: 3 beta-hydroxysteroid dehydrogenase/isomerase and aromatase activity in primary cultures of developing zebra finch telencephalon: dehydroepiandrosterone as substrate for synthesis of androstenedione and estrogens. Gen Comp Endocrinol 1996, 102:342-350.

18. Itoh Y, Melamed E, Yang X, Kampf K, Wang S, Yehya N, Van Nas A, Replogle K, Band MR, Clayton DF, Schadt EE, Lusis AJ, Arnold AP: Dosage compensation is less effective in birds than in mammals. J Biol 2007, $6: 2$

19. London SE, Schlinger BA: Steroidogenic enzymes along the ventricular proliferative zone in the developing songbird brain. J Comp Neurol 2007, 502:507-521.

20. Gahr M, Metzdorf R: Distribution and dynamics in the expression of androgen and estrogen receptors in vocal control systems of songbirds. Brain Res Bull 1997, 44:509-517.

21. Jacobs EC, Arnold AP, Campagnoni AT: Developmental regulation of the distribution of aromatase- and estrogen-receptor-mRNA-expressing cells in the zebra finch brain. Dev Neurosci 2000, 21:453-472.

22. Perlman WR, Arnold AP: Expression of estrogen receptor and aromatase mRNAs in embryonic and posthatch zebra finch brain. $J$ Neurobiol 2003, 55:204-219.

23. Perlman WR, Ramachandran B, Arnold AP: Expression of androgen receptor $\mathrm{mRNA}$ in the late embryonic and early posthatch zebra finch brain. J Comp Neurol 2003, 455:513-530.

24. Rone MB, Fan J, Papadopoulos V: Cholesterol transport in steroid biosynthesis: role of protein-protein interactions and implications in disease states. Biochim Biophys Acta 2009, 1791:646-658.

25. Miller WL: Steroidogenic acute regulatory protein (StAR), a novel mitochondrial cholesterol transporter. Biochim Biophys Acta 2007, 1771:663-676

26. Papadopoulos V, Liu J, Culty M: Is there a mitochondrial signaling complex facilitating cholesterol import? Mol Cell Endocrinol 2007, 265266:59-64.

27. Papadopoulos V: In search of the function of the peripheral-type benzodiazepine receptor. Endo Res 2004, 30:677-684.

28. Papadopoulos V, Baraldi M, Guilarte TR, Knudsen TB, Lacapere JJ, Lindemann P, Norenberg MD, Nutt D, Weizman A, Zhang MR, Gavish M: Translocator protein $(18 \mathrm{kDa})$ : new nomenclature for the peripheral- type benzodiazepine receptor based on its structure and molecular function. Trends Pharmacol Sci 2006, 27:402-409.

29. Lacapere JJ, Papadopoulos V: Peripheral-type benzodiazepine receptor: structure and function of a cholesterol-binding protein in steroid and bile acid biosynthesis. Steroids 2003, 68:569-585.

30. Baker ME: Evolution of 17beta-hydroxysteroid dehydrogenases and their role in androgen, estrogen and retinoid action. Mol Cell Endocrinol 2001, 171:211-215.

31. Simard J, Ricketts ML, Gingras S, Soucy P, Feltus FA, Melner MH: Molecular biology of the 3beta-hydroxysteroid dehydrogenase/delta5-delta4 isomerase gene family. Endocr Rev 2005, 26:525-582.

32. Lukacik P, Kavanagh KL, Oppermann U: Structure and function of human 17beta-hydroxysteroid dehydrogenases. Mol Cell Endocrinol 2006, 248:61-71.

33. Owen $\mathrm{Gl}$, Zelent A: Origins and evolutionary diversification of the nuclear receptor superfamily. Cell Mol Life Sci 2000, 57:809-827.

34. Payne AH, Abbaszade IG, Clarke TR, Bain PA, Park CH: The multiple murine 3 beta-hydroxysteroid dehydrogenase isoforms: structure, function, and tissue- and developmentally specific expression. Steroids 1997, 62:169-175

35. McBride MW, Mcvie AJ, Burridge SM, Brintnell B, Craig N, Wallace AM, Wilson RH, Varley J, Sutcliffe RG: Cloning, expression, and physical mapping of the 3 beta-hydroxysteroid dehydrogenase gene cluster (HSD3BP1-HSD3BP5) in human. Genomics 1999, 61:277-284.

36. Payne AH, Hales DB: Overview of steroidogenic enzymes in the pathway from cholesterol to active steroid hormones. Endo Rev 2004, 25:947-970

37. Bain PA, Meisler MH, Taylor BA, Payne AH: The genes encoding gonadal and nongonadal forms of 3 beta-hydroxysteroid dehydrogenase/delta 5-delta 4 isomerase are closely linked on mouse chromosome 3. Genomics 1993, 16:219-223.

38. Schwarz M, Wright AC, Davis DL, Nazer H, Bjorkhem I, Russell DW: The bile acid synthetic gene 3beta-hydroxy-Delta(5)-C(27)-steroid oxidoreductase is mutated in progressive intrahepatic cholestasis. $J$ Clin Invest 2000, 106:1175-1184.

39. Prehn C, Moller G, Adamski J: Recent advances in 17beta-hydroxysteroid dehydrogenases. J Steroid Biochem Mol Biol 2009, 114:72-77.

40. Itoh Y, Kampf K, Arnold AP: Comparison of the chicken and zebra finch Z chromosomes shows evolutionary rearrangements. Chromosome Res 2006, 14:805-815

41. Melamed E, Arnold AP: Regional differences in dosage compensation on the chicken Z chromosome. Genome Biol 2007, 8:R202.

42. Arnold AP: Genetically triggered sexual differentiation of brain and behavior. Horm Behav 1996, 30:495-505.

43. Arnold AP: Sexual differentiation of the zebra finch song system: Positive evidence, negative evidence, null hypotheses, and a paradigm shift. J Neurobio/ 1997, 33:572-584.

44. Chen $X$, Agate RJ, Itoh Y, Arnold AP: Sexually dimorphic expression of trkB, a Z-linked gene, in early posthatch zebra finch brain. Proc Natl Acad Sci USA 2005, 102:7730-7735.

45. Tomaszycki ML, Peabody C, Replogle K, Clayton DF, Tempelman RJ, Wade $\mathrm{J}$ : Sexual differentiation of the zebra finch song system: Potential roles for sex chromosome genes. BMC Neurosci 2009, 10:24

46. Luo M, Yu Y, Kim H, Kudrna D, Itoh Y, Agate RJ, Melamed E, Goicoechea JL, Talag J, Mueller C, Wang W, Currie J, Sisneros NB, Wing RA, Arnold AP: Utilization of a zebra finch BAC library to determine the structure of an avian androgen receptor genomic region. Genomics 2006, 87:181-190.

47. Chow JDY, Simpson ER, Boon WC: Alternative 5'-untranslated first exons of the mouse Cyp19A1 (aromatase) gene. J Steroid Biochem Mol Biol 2009, 115:115-125.

48. Ramachandran B, Schlinger BA, Arnold AP, Campagnoni AT: Zebra finch aromatase gene expression is regulated in the brain through an alternate promoter. Gene 1999, 240:209-216.

49. Sharma D, Ghai S, Singh D: Different promoter usage for CYP19 gene expression in buffalo ovary and placenta. Gen Comp Endocrinol 2009, 162:319-328.

50. Wang H, Li R, Hu Y: The alternative noncoding exons 1 of aromatase (Cyp19) gene modulate gene expression in a posttranscriptional manner. Endocrinology 2009, 150:3301-3307.

51. Zhao H, Innes J, Brooks DC, Reierstad S, Yilmaz MB, Lin Z, Bulun SE: A novel promoter controls Cyp19al gene expression in mouse adipose tissue. Reprod Biol and Endocrinol 2009, 7:37. 
52. Simpson ER, Michael MD, Agarwal VK, Hinshelwood MM, Bulun SE, Zhao Y: Expression of the CYP19 (aromatase) gene: An unusual case of alternative promoter usage. FASEB Journal 1997, 11:29-36.

53. Honda SI, Harada N, Takagi Y: The alternative exons 1 of the mouse aromatase cytochrome P-450 gene. Biochimica et Biophysica Acta - Gene Structure and Expression 1996, 1305:145-150.

54. Warren WC, Clayton DF, Ellegren H, Arnold AP, Hillier LW, Kunstner A Searle S, White S, Vilella AJ, Heger A, Kong L, Ponting CP, Jarvis E, Mello CV, Minx P, Yang S-P, Lovell P, Velho TAF, Ferris M, Balakrishnan CN, Sinha S, Blatti C, London SE, Li Y, Lin Y-C, George J, Sweedler J, Southey B, Gunaratne $\mathrm{P}$, Watson $\mathrm{M}$, et al: The genome sequence of the vocal learning zebra finch. Nature 2009 in press.

55. Alaux C, Sinha S, Hasadsri L, Hunt GJ, Guzman-Novoa E, DeGrandiHoffman G, Uribe-Rubio JL, Southey BR, Rodriguez-Zas S, Robinson GE: Honey bee aggression supports a link between gene regulation and behavioral evolution. Proc Natl Acad Sci USA 2009, 106:15400-15405.

56. Dong S, Replogle KL, Hasadsri L, Imai BS, Yau PM, Rodriguez-Zas S, Southey BR, Sweedler JV, Clayton DF: Discrete molecular states in the brain accompany changing responses to a vocal signal. Proc Natl Acad SciUSA 2009, 106:11364-11369.

57. Replogle K, Arnold AP, Ball GF, Band M, Bensch S, Brenowitz EA, Drnevich J, Ferris M, George JM, Gong G, Hasselquist D, Hernandez AG, Kim R, Lewin HA, Liu L, Lovell PV, Mello CV, Naurin S, Rodriguez-Zas S, Thimmapuram J, Wade J, Clayton DF: The Songbird Neurogenomics (SoNG) Initiative: Community-based tools and strategies for study of brain gene function and evolution. BMC Genomics 2008, 9:124.

58. Cheng HY, Clayton DF: Activation and habituation of extracellular signal-regulated kinase phosphorylation in zebra finch auditory forebrain during song presentation. J Neurosci 2004, 24:7503-7513.

59. Bolhuis JJ, Gahr M: Neural mechanisms of birdsong memory. Nat Rev Neurosci 2006, 7:347-357.

60. London SE, Clayton DF: Functional identification of sensory mechanisms required for developmental song learning. Nat Neurosci 2008, 11:579-586

61. Mello CV, Velho TAF, Pinaud R: Song-induced gene expression: A window on song auditory processing and perception. Ann N Y Acad Sci 2004, 1016:263-281.

62. Peltoketo H, Luu-The V, Simard J, Adamski J: 17beta-hydroxysteroid dehydrogenase (HSD)/17-ketosteroid reductase (KSR) family; nomenclature and main characteristics of the 17HSD/KSR enzymes. $J$ Mol Endocrinol 1999, 23:1-11.

63. Oppermann U, Filling $C$, Hult M, Shafqat N, Wu XQ, Lindh M, Shafqat J, Nordling E, Kallberg Y, Persson B, Jornvall H: Short-chain dehydrogenases/reductases (SDR): the 2002 update. ChemicoBiological Interactions 2003, 143:247-253.

64. Moeller G, Adamski J: Integrated view on 17beta-hydroxysteroid dehydrogenases. Mol and Cellular Endocrinol 2009, 301:7-19.

65. Moeller G, Adamski J: Multifunctionality of human 17 betahydroxysteroid dehydrogenases. Mol and Cell Endocrinol 2006 248:47-55.

66. Napoli JL: 17 beta-Hydroxysteroid dehydrogenase type 9 and other short-chain dehydrogenases/reductases that catalyze retinoid, 17 beta- and 3 alpha-hydroxysteroid metabolism. M Mol and Cell Endocrinol 2001, 171:103-109.

67. Haapalainen AM, Koski MK, Qin YM, Hiltunen JK, Glumoff T: Binary structure of the two-domain (3R)Hydroxyacyl-CoA dehydrogenase from rat peroxisomal multifunctional enzyme type 2 at 2.38 angstrom resolution. Structure 2003, 11:87-97.

68. Breitling R, Marijanovic Z, Perovic D, Adamski J: Evolution of 17 beta-HSD type 4, a multifunctional protein of beta-oxidation. Mol and Cell Endocrinol 2001, 171:205-210.

69. Marijanovic Z, Laubner D, Moller G, Gege C, Husen B, Adamski J, Breitling $R$ : Closing the gap: I dentification of human 3-ketosteroid reductase, the last unknown enzyme of mammalian cholesterol biosynthesis. Mol Endocrinol 2003, 17:1715-1725.

70. Shehu A, Halperin J: Prolactin Receptor-Associated Protein/17 betaHydroxysteroid Dehydrogenase Type 7 Gene (Hsd17b7) Plays a Crucial Role in Embryonic Development and Fetal Survival. Mol Endocrinol 2008, 22:2766-2268

71. Mindnich R, Moller G, Adamski J: The role of 17 beta-hydroxy steroid dehydrogenases. Mol and Cell Endocrinol 2004, 218:7-20.
72. Liu H, Bellemare V, Labrie F, Luu-The V: Molecular characterization of the cynomolgus monkey Macaca fascicularis steroidogenic enzymes belonging to the aldo-keto reductase family. J Steroid Biochem and Mol Biol 2007, 104:75-80.

73. Luu-The V, Tremblay P, Labrie F: Characterization of type 1217 betahydroxysteroid dehydrogenase, an isoform of type 317 betahydroxysteroid dehydrogenase responsible for estradiol formation in women. Mol Endocrinol 2006, 20:437-443.

74. Baker ME: Evolution of mammalian 11 beta- and 17 betahydroxysteroid dehydrogenases-type 2 and retinol dehydrogenases from ancestors in Caenorhabditis elegans and evidence for horizontal transfer of a eukaryote dehydrogenase to E-coli. J Steroid Biochem and Mol Biol 1998, 66:355-363.

75. Suzumori N, Yan CN, Matzuk MM, Rajkovic A: Nobox is a homeoboxencoding gene preferentially expressed in primordial and growing oocytes. Mech Dev 2002, 111:137-141.

76. Nilsson M, Stulnig TM, Lin CY, Yeo AL, Nowotny P, Liu ET, Steffensen KR: Liver $X$ receptors regulate adrenal steroidogenesis and hypothalamicpituitary-adrenal feedback. Mol Endocrinol 2007, 21:126-137.

77. Giatzakis C, Papadopoulos V: Differential utilization of the promoter of peripheral-type benzodiazepine receptor by steroidogenic versus nonsteroidogenic cell lines and the role of Sp1 and Sp3 in the regulation of basal activity. Endocrinology 2004, 145:1113-1123.

78. Lavoie HA, King SR: Transcriptional regulation of steroidogenic genes: STARD1, CYP11A1 and HSD3B. Exp Biol Med (Maywood) 2009, 234:880-907.

79. Manna PR, Dyson MT, Stocco DM: Role of basic leucine zipper proteins in transcriptional regulation of the steroidogenic acute regulatory protein gene. Mol Cell Endocrinol 2009, 302:1-11.

80. Lewis SE, Searle SM, Harris N, Gibson M, Lyer V, Richter J, Bayraktaroglir L, Birney E, Crosby MA, Kaminker JS, Matthews BB, Prochnik SE, Smithy CD, Tupy JL, Rubin GM, Misra S, Mungall CJ, Clamp ME: Apollo: a sequence annotation editor. Genome Biol 2002, 3:RESEARCH0082.

81. Katoh K, Toh H: Recent developments in the MAFFT multiple sequence alignment program. Briefings in Bioinformatics 2008, 9:286-298

82. Katoh K, Misawa K, Kuma K, Miyata T: MAFFT: a novel method for rapid multiple sequence alignment based on fast Fourier transform. Nucleic Acids Res 2002, 30:3059-3066.

83. Kumar S, Nei M, Dudley J, Tamura K: MEGA: A biologist-centric software for evolutionary analysis of DNA and protein sequences. Briefings in Bioinformatics 2008, 9:299-306

84. Tamura K, Dudley J, Nei M, Kumar S: MEGA4: Molecular evolutionary genetics analysis (MEGA) software version 4.0. Mol Biol Evol 2007, 24:1596-1599.

85. Lovell PV, Clayton DF, Replogle KL, Mello CV: Birdsong "transcriptomics": neurochemical specializations of the oscine song system. PLOS ONE 2008, 3:e3440.

86. Jin $\mathrm{H}$, Clayton DF: Localized changes in immediate-early gene regulation during sensory and motor learning in zebra finches. Neuron 1997, 19:1049-1059.

87. Mello CV, Vicario DS, Clayton DF: Song presentation induces gene expression in the songbird forebrain. Proc Natl Acad Sci USA 1992, 89:6818-6822

doi: $10.1186 / 1471-2202-11-46$

Cite this article as: London and Clayton, Genomic and neural analysis of the estradiol-synthetic pathway in the zebra finch BMC Neuroscience 2010, 11:46 